Вестник РУДН. Серия: Инженерные исследования

2019 Том 20 № 1 C. $66-78$

journals.rudn.ru/engineering-researches

Research paper

DOI 10.22363/2312-8143-2019-20-1-66-78

UDC 528.8.04

\title{
Application of remote sensing for monitoring of flood areas
}

\author{
N. Suárez Kozov*, D. Trujillo Osorio ${ }^{\dagger}$, J. Giraldo Osorio ${ }^{\ddagger}$ \\ * Peoples' Friendship University of Russia (RUDN University), 6 Miklukho-Maklaya St., Moscow, 117198, Russian Federation \\ † Pontificia Universidad Javeriana, Carrera 7 No. 40-62, Bogotá 11023, Colombia
}

Article history:

Received: November 02, 2018

Revised: January 15, 2019

Accepted: January 29, 2019

\section{Keywords:}

remote sensing;

subpixel flood areas;

subpixels;

resolution;

coverage
Traditional measurement techniques "in situ" sometimes fail to magnify the spatial distribution of floods. For these cases, the remote sensors provide methodologies of very low economic cost and high reliability when mapping flooded areas and quantifying the damages. Due to the dynamic nature of these phenomena, it is necessary to use satellite images of high temporal resolution, however this type of images usually have a low spatial resolution. In relation to this problem, traditional classification techniques are not reliable enough for flood delineation and monitoring since they use "hard methods" of classification, where the coarse pixel is assigned a single type of coverage. On the other hand, "smoothed methods" have the ability to assign different kinds of coverage to the interior of the thick pixel. The present investigation makes the application of a sub-pixel analysis methodology (sub-pixel analysis - SA) for the monitoring of flooded areas. The improvement of the delimitation is achieved with the use of topographic attributes provided by a digital terrain model (DTM). The methodology was applied to the monitoring in the Great Depression Momposina, specifically to delineate the swamp of Zapatosa.

\section{Introduction}

The human, always in expansion, takes territory away from nature, increasing the affectation caused by natural disasters, such as earthquakes, tornadoes, hurricanes, storms, floods, droughts, etc. Some of these phenomena can be decimated in their damages with systems early alarms and their evolutions can be monitored. This is why it is important to use tools such as satellite images to support the characterization and study of terrestrial phenomena. It is a topic of general interest, to have a tool at your fingertips which allows you to take free information from the different remote sensors such as the MODIS and Landsat and to transform it into useful information to delve into the natural phenomena that overwhelm the Earth.

Empirical sciences such as topography and photogrammetry have been emerging, as well as meteorology for the climatological study. However, several of these disciplines require obtaining data from

\footnotetext{
* Master student of Construction Department, Academy of Engineering; nikolaysuarez@gmail.com

$\dagger$ Magister of Department of Construction

* Associate Professor of Department of Construction, Polytechnical University of Cartagena, PhD in Water Resources Management

(C) Suárez Kozov N., Trujillo Osorio D., Giraldo Osorio J., 2019
} 
a fieldwork, using specialized teams in each of the areas. Therefore, they require imminent displacement to the study area, sometimes finding unsuitable conditions for work, due to difficult accessibility. Man has been able to facilitate tasks that do not require physical presence, equipment such as satellites solve problems in which there were technical limitations, thus facilitating tasks such as obtaining instant results [1].

Currently, there is the geographic information systems (GIS), which provide effective tools for dealing with temporary space data, in addition to which they are very effective for archiving, displaying, analyzing and modeling geographic data when combining sociopolitical data such as borders and inhabited areas, these tools are useful for correct decision-making [2]. An example of this was the use of a GIS implemented by the Center for Research on Drought (CEISS) in Chihuahua (Mexico) as support for decision making which allowed permanently assess the areas that were affected by drought [3].

Another application of this technology is the magnification and mapping groundwater in northern Ethiopia, more precisely in the Valle de Raya [4]. The representation of this information was made graphically through a GIS, represented by layers schematic data such as areas of plant cover, populations, location of major livestock producers, until the presence of pollutants in watercourses. With the superposition of these data, very complete models are generated capable of modeling the behavior of droughts [3]. The dynamics of these phenomena is very high to achieve an adequate analysis satellite images with high resolution are required. The problem with this type of images is their temporal resolution since the time between each of them is very long, relatively with the duration of these natural phenomena. However, there are satellite images with a higher temporal resolution, making possible in the best of cases a daily collection of information to carry out a valid monitoring. Because the spatial resolution of these high-resolution temporal images is, in general, very poor, many of the relevant data are lost because of the quality of the information. In response to this problem, there are sub-pixel analysis methodologies (sub-pixel analysis - SA), which use satellite images of moderate spatial resolution for these analyzes, demonstrating an efficiency of $80 \%$ in the correct allocation of flooded areas [5]. As the main input of this project, we have a code base in language " $\mathrm{C}$ ", which is capable of executing the methodology; as an input parameter it receives a satellite image of moderate spatial resolution, and as a result it performs a classification of the image scenario at the subpixel level (with spatial resolution finer than the original satellite image). To verify the goodness of the classification, confusion matrices will be used between the result and a high-resolution satellite image.

\section{Materials and methods}

The sub-pixel methodology developed in that work was initially proposed in [5] where different mathematical models are used to validate hypotheses about the relationship between the spectral signatures, their proportion within and behavior in relation to the topography in a satellite image, which in the present work received modifications, which increase its effectiveness. The process of operation can be summarized in the Figure 1.

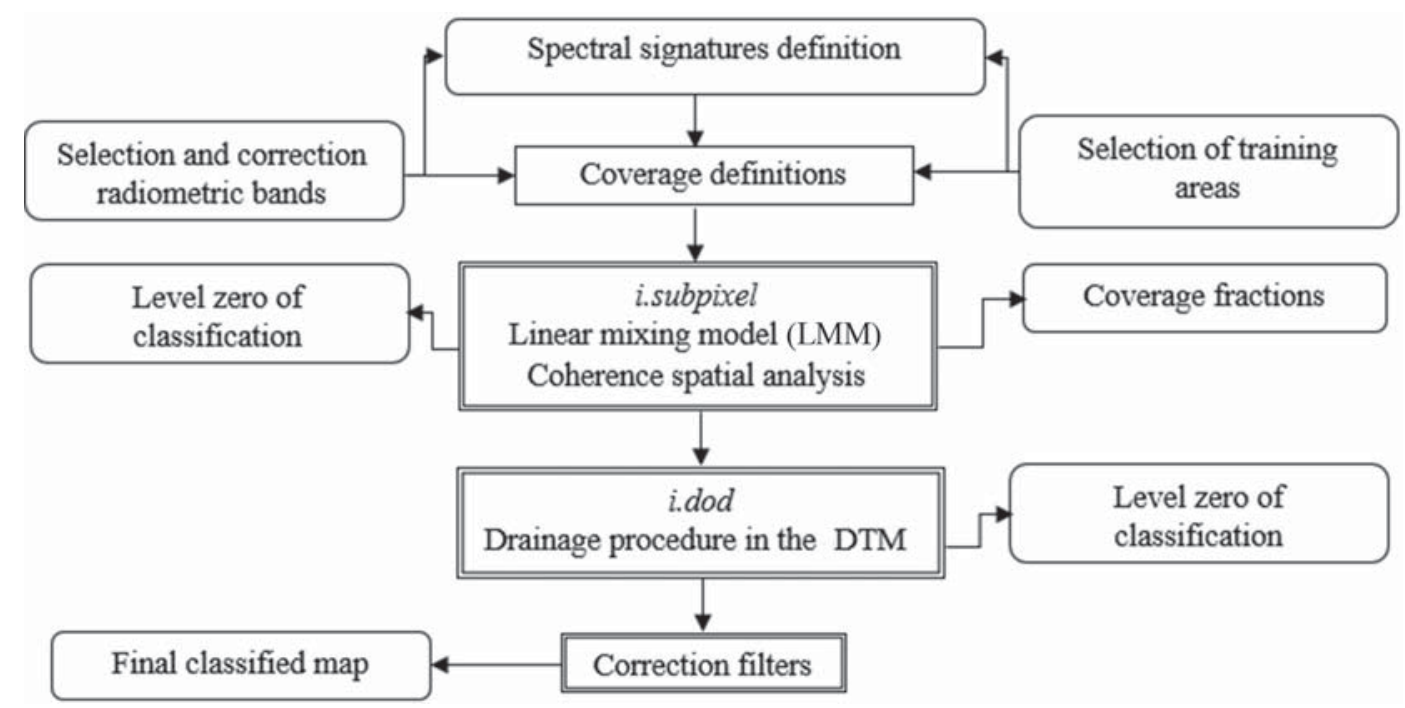

Figure 1. Sub-pixel methodology [5] 


\section{1. Linear mixing model (LMM)}

The surfaces have unique spectral signatures which can be identified, therefore when a sensor of low spectral resolution that measures a thick pixel, it contains the linear combination of the radiations that are reflected in its interior. These types of well-discriminated coverages are called pure classes. However, the objective of the LMM is to abstract from the gross pixel the quantity of pure classes and the respective proportion, of the whole image and of the bands used in the analysis. To solve the previous unknowns the analysis is based on the solution of a system of equations with restrictions. Therefore, as was proposed in [5], the mathematical model can be represented in the following way:

$$
R=E \cdot f+\varepsilon .
$$

Fulfilling

$$
\left\{\begin{array}{l}
l^{T} \times f=1 \\
0 \leq f_{\Psi} \leq 1
\end{array},\right.
$$

where $R$ is the vector $n \times l$ that has the multispectral observation of the gross pixel; $E$ represents the $n \times c$ matrix, where the elements $E_{(\Omega, \Psi)}$ are the spectral response of each pure class $\Psi$ in the band $\Omega ; f$ is the vector containing the solution of the coverage fractions; $\varepsilon$ is the residual error $n \times l$ vector; $l$ vector symbolizes $c \times l$, where $l^{T}=[1,1, \ldots, 1] ; n$ is the number of bands used and $c$ is the number of coverage classes.

The laws are very simple, the first law tries to express that the sum of the proportions of coverages within the gross pixel must be equal to one and is called sum constraint equal to one [5]. The second law proposes the restriction so that the contribution of each coverage is positive and in no way can be negative (positive restriction).

The solution can be found by raising the LMM as an optimization problem is based on the equations of this, that is, the equation of the vector of proportions $R$ adding an error to the measurement, and restrictions of sum one and non-negativity, being the model mathematical proposed in [7].

At this point Lagrange multipliers are the ideal tool proposed by [7] to solve the optimization problem posed above, for this case the Lagrange equation would be given as follows:

$$
\begin{gathered}
L\left(f_{1}, f_{2}, \ldots, f_{c}, \lambda\right)= \\
=\sum_{\Omega=1}^{n}\left[R_{\Omega}-R_{\Omega^{*}}\right]^{2}-\lambda \times\left[\sum_{\Psi=1}^{c} f_{\Psi}-1\right] .
\end{gathered}
$$

For the equation (2), we consider that $R_{\Omega}=R(\Omega)$, $R_{\Omega^{*}}=R(\Omega)^{*}, f_{\Psi}=f(\Psi)$ to have an easier notation. In the previous equation, it is well known that only the restriction of sum equal to one of the LMM is considered, due to the complexity of the non-negativity restriction, this will be implemented later if it becomes necessary.

When deriving and equaling zero, we propose a system of equations with $c+1$ equations, which have as unknowns $f_{1}, f_{2}, f_{3}, \ldots, f_{c}$ and $\lambda$, therefore the resulting derivatives are:

$$
\frac{\partial L}{\partial \lambda}=0=1-\sum_{\Psi=1}^{c} f
$$

This system can be solved with the following expression:

$$
K \times f_{\lambda}=C .
$$

Within this matrix $K_{j i}$ and $C_{i}$ symbolize the following equations:

$$
\begin{aligned}
K_{j i} & =2 \times \sum_{k=1}^{n} E(k, j) \times E(k, i) . \\
C & =2 \times \sum_{k=1}^{n} R(k) \times E(k, j) .
\end{aligned}
$$

For this case, the matrix $K$ is symmetric. To solve this system of equations is used the factorization type LU (lower - upper) of the matrix $K$. The factorization by the method of Cholesky is not possible since $K$ is semidefinite and positive. The sum constraint equal to one is guaranteed in the system $K \times f_{\lambda}=C f_{k}$, however the non-negativity constraint cannot be fulfilled since the solution vector $f_{k}$ can be less than zero.

According to the work [5], a solution for the vector $f_{\lambda}$ is proposed within the region considered feasible. At the moment of presenting a negative value in the vector $f_{k}$ the construction of a new system identical to the previous one is considered, however in this the $k$-th row and column of the matrix is eliminated, in the same way for the vectors $f_{\lambda}$ and $C$ will eliminate the $k$-th element.

$$
K_{\mathrm{RED}} \times f_{\lambda-\mathrm{RED}}=C_{\mathrm{RED}} .
$$

With the vector $f_{\lambda-\text { RED }}$ the system is solved, so it is possible to complete the solution vector $f_{\lambda}$ using values of 0 in the $k$-th position, if the negative values persist in the vector $f_{\lambda-\mathrm{RED}}$, it is possible to repeat the elimination and impersonation procedure of these values by zero if they are already presented once this method has been executed. The use of Lagrange multipliers brings greater 
speed in the identification of proportions as a benefit, because it works more like an analytical process and not an iterative one according to [5].

\subsection{Spatial coherence analysis}

As it proposed in [8] the problem calve to make a correct classification sub-pixel is to assume that there is a certain relationship or spatial dependence between the sub-pixels inside and around the thick pixel, at the moment of dividing the thick pixel into small units or sub-pixels, a class of coverage is assigned to the new unit within the thick pixel.

In [9] they formulate the sub-pixel map as a linear optimization problem: it is assumed that the LMM contains $C$ classes of coverages and that the resolution of the coarse pixel is divided into $N$ sub-pixels. The number of sub-pixels that is assigned to coverage class $i$ is $N C i$, derived from the fractional image. The spatial dependence will be calculated for each coverage class $i$ and for each sub-pixel $j$. In each sub-pixel must be assigned a value of 1 or 0 for each coverage class, the value of 1 indicates that in place there is presence of the target coverage class, therefore the problem becomes the assignment of classes of coverage to sub-pixels and maximize spatial dependence. For the construction of the mathematical model, the variables $X_{i j}$ were used and defined as:

$$
X_{i j}=\left\{\begin{array}{l}
1 \\
0
\end{array} 1,\right.
$$

if the sub-pixel $j$ contains the coverage class $i$, else 0 .

Therefore, the mathematical model can be expressed as follows:

$$
\max (z)=\sum_{i=1}^{C} \sum_{j=1}^{N} X_{i j} \times C_{i j} .
$$

Assigning the following to the above equation:

$$
\left\{\begin{array}{l}
\sum_{i=1}^{C} X_{i j}=1 \quad j=1,2, \ldots, N \\
\sum_{j=1}^{N} X_{i j}=N C i \quad i=1,2, \ldots, C .
\end{array}\right.
$$

After declaring the mathematical model, they proceed with the construction of a cost matrix for each type of coverage. The previously proposed restrictions are understood as:

- the first rule ensures that only a single coverage class is assigned to the sub-pixel $(i, j)$;

- the aim of the second rule is to ensure for the $N C^{(\Psi)}$ sub-pixels the class $\Psi$ is assigned correctly.

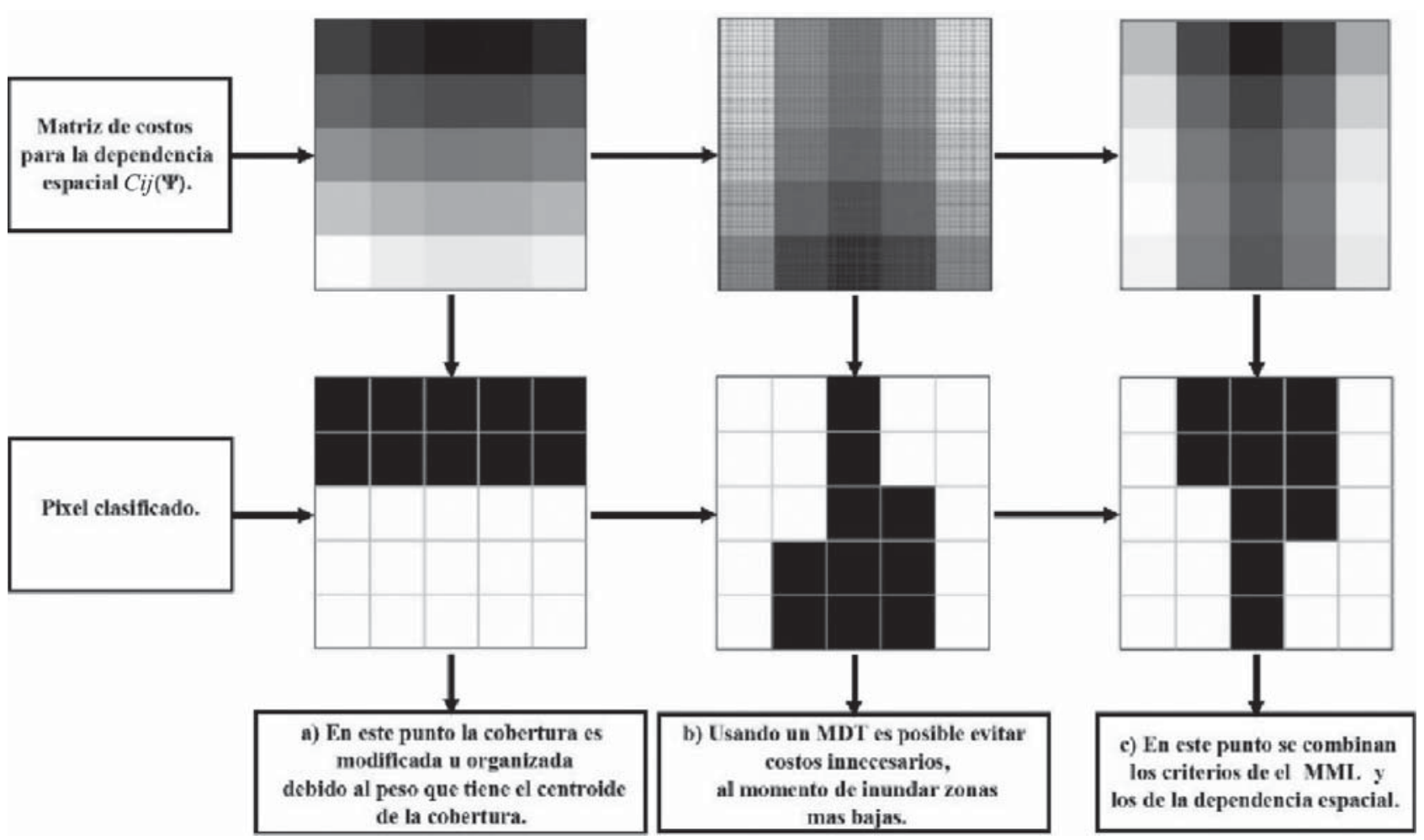

Figure 2. Scheme use cost matrix for the analysis of spatial coherence [6] 
These functions and restrictions are linear in nature, so they can be solved by applying linear programming [8].

\subsection{Costs Matrix}

At this point, the cost matrix $C_{i j}{ }^{(\Psi)}$ is necessary to solve the system of equations, to use this tool we start from previous hypotheses who was developed in [5] about the distribution of classes within the pixel:

- for there to be a class grouping $\Psi$ it must be given around a centroid of that class;

- the topography is a determining factor for the identification of "water" or "flooded" zones, therefore these classes will always be generated and will flow towards low areas.

The diagram (Figure 2) explains how the cost matrix works for spatial coherence, in the lower part of the diagram are the assignments of the "water" or "flooded" coverage made by the cost matrices, where the dark colors represent the lower values and vice versa in relation to light colors that represent high values.

a) The cost matrix is generated, considering only the principles of spatial coherence, using the distribution of the coverage fractions a centroid has been generated, in this case the costs will be lower depending on its proximity to it.

b) The cost matrix generated with the principles related to the DTM of the gross pixel area is presented, in this case, the lowest values in the DTM will be the indicators for the lower areas.

c) The combination of the criteria of $a$ and $b$ allows a sub-pixel assignment more coherent with principles of spatiality (neighboring values) and topography.

\subsection{DTM and DOD drainage networks}

Through a modification of the method proposed in [10], which generates a cost matrix, which aims to calculate the route with the lowest cost from a point (a) to a point (b). Specifying the DTM becomes the cost matrix and points (a) and (b) are the accumulation zones, in this way there will be drainage lines or lines between the two points, which in turn are based on the amount of times that drainage lines cross a pixel, verifying its class whether it is "flooded" or "dry".

This method is modified [5] in which the proposed solution uses the directions of the flow to generate aggregation of new "flooded" class pixels. As inputs to this method use the map of drainage directions and the map of accumulations, which are products of the DTM.

This process is based on assigning with a value of +1 to the class pixels "flooded" and a value of -1 to the "dry" class pixels in the initial conditions. As a premise, an amount $n$ of sub-pixels will accumulate in the direction of the flow, as long as it is "flooded" and $n-1$ for the sub-pixels of the "dry" class. It is necessary to highlight that this algorithm works using the direction of the flow. The algorithm only accumulates for those sub-pixels that have a value greater than zero, in the case of the sub-pixels of value -1 upstream it will not subtract or add to the value of the downstream pixel, however this can become zero because it has a sub-pixel "flooded" Upstream, as a final result, all those sub-pixels that end with a positive value, and different from zero will be classified as "flooded".

\section{Results}

To execute the sub-pixel methodology and the drainage network methodology in the digital terrain model, the commands called i.subpixel and i.dod were designed in [5] to be executed in the GRASS GIS free software. However, due to software update effects, these had to be modified in some of their functions present in their base code to work correctly in GRASS GIS V.7.0.

\subsection{Study area for implementation of the methodology}

The study area corresponds to the water mirror of the depression Momposina called "Cienaga Candelaria Rincón Avisperos", belonging to the complex of bodies of water known as "Cienaga de Zapatosa". This water mirror is formed in a delta of Magdalena River. For this study area, the examples and results are based on the DTM present in Figure 3. This DTM was processed and used with a spatial resolution of 50 meters, which is a resampling of the digital topography with a spatial resolution 30-meter original downloaded from the official USGS website.

\subsection{Results command i.subpixel (level 0 of classification)}

Two types of products can be obtained from the i.subpixel command, both of them very important for the analysis of the types of coverages present in our study area. The first of these products are the maps of coverage fractions, which will be equal to the number of classes that are defined at the time of the supervised classification; that is, each map will show only the pixels of the class in which it is focused, the rest will have a value of 0 , the value of the pixels in which the class is present will be a function of the proportion of that class in that pixel. Below in Figure 4 you can see the maps of coverage 
fractions for the five classes resulting from the supervised classification, these focused on identifying water bodies, bare soil and vegetation.

The maps of proportions of coverage provide us with the vision of the distribution of the different classes of coverages over the gross pixel, those presented and produced by this command are in units of percentage from 0 to $100 \%$, where 0 is the absolute absence of the class in question and $100 \%$ as the true and absolute presence of this. In the maps, the units go from zero to 10000 , the highest value being the equivalent of $100 \%$.

As a result of the methodology (classified map of level 0 ) is the map of Figure 5. This figure shows the base map for the following steps. The map originally had a resolution of 500 meters and the resulting i.subpixel module has a resolution of 50 meters. To make this analysis clearer, this map is reclassified into two clear classes, one referring to bodies of water and the other referring to coverings of soil and vegetation.

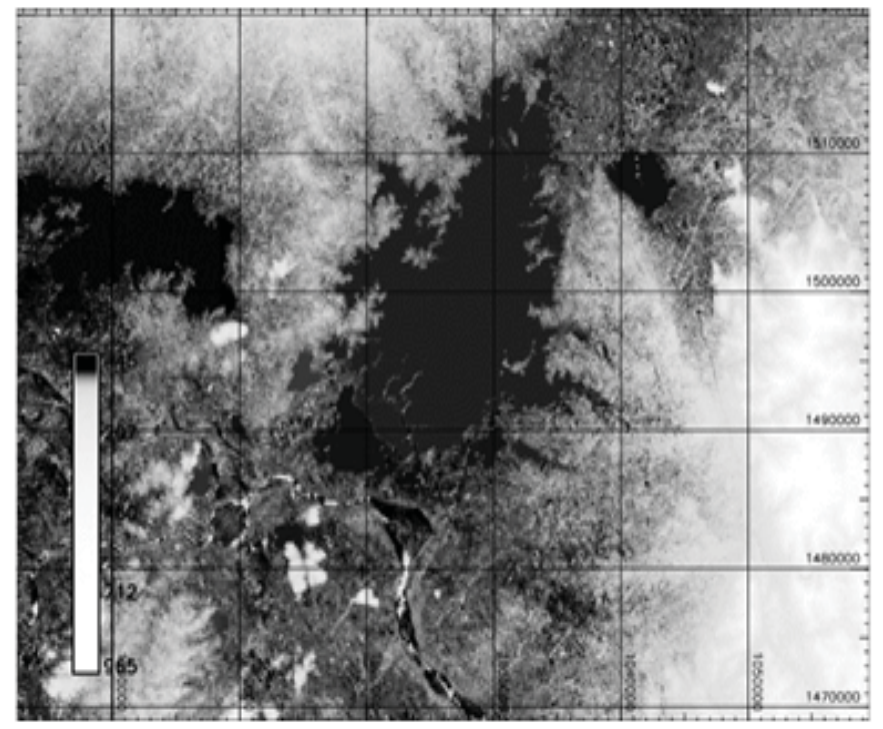

Figure 3. Digital terrain model of the study area

Source: U.S. Geological Survey. URL: www.usgs.gov
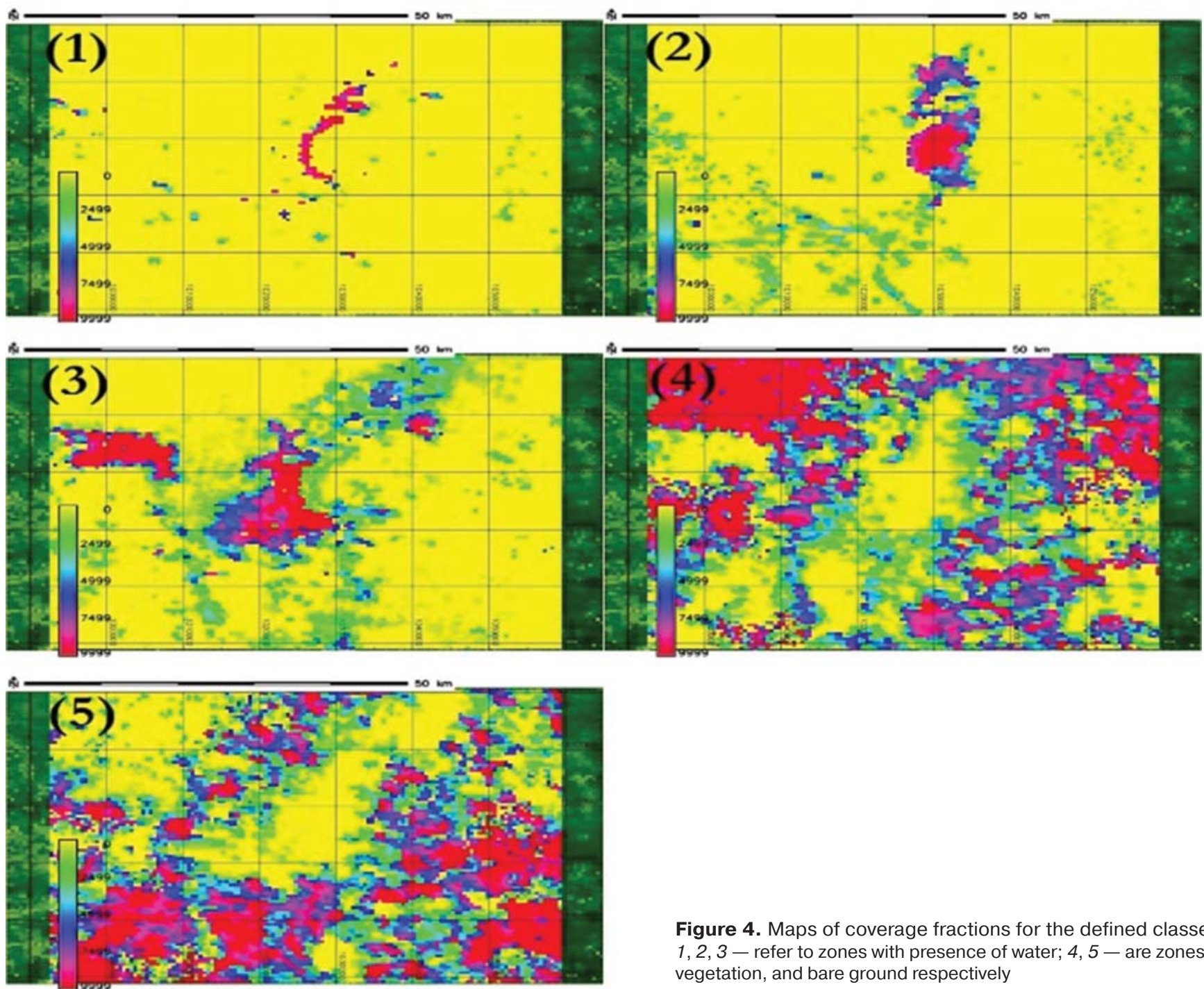

Figure 4. Maps of coverage fractions for the defined classes: $1,2,3$ - refer to zones with presence of water; 4, 5- are zones of vegetation, and bare ground respectively 


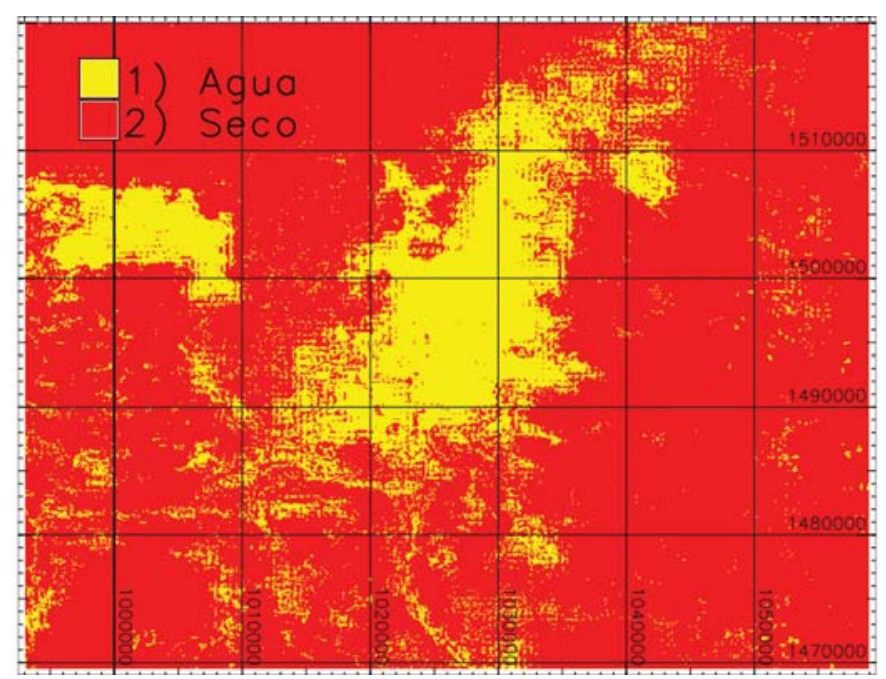

Figure 5. Map two classes (i.subpixel): yellow - water class; red - dry class

\subsection{Results command i.dod (level 1 classification)}

This command receives as inputs the accumulation maps and drainage directions obtained from the digital terrain model in the final resolution of the i.subpixel, i.e. $50 \mathrm{~m}$, and the map resulting from level 0 of the classification. At this point, the working resolution must be the resolution of the output map of the i.subpixel command. The map resulting from this module is presented in Figure 6, which has the same sub-pixel classification map metadata, it should be noted that the i.dod module can be applied several times to improve its effect. It is noticeable how the algorithm extrapolates the "water" class zones using drainage and accumulated flow networks, both in the lotic water body and in the lentic water body.

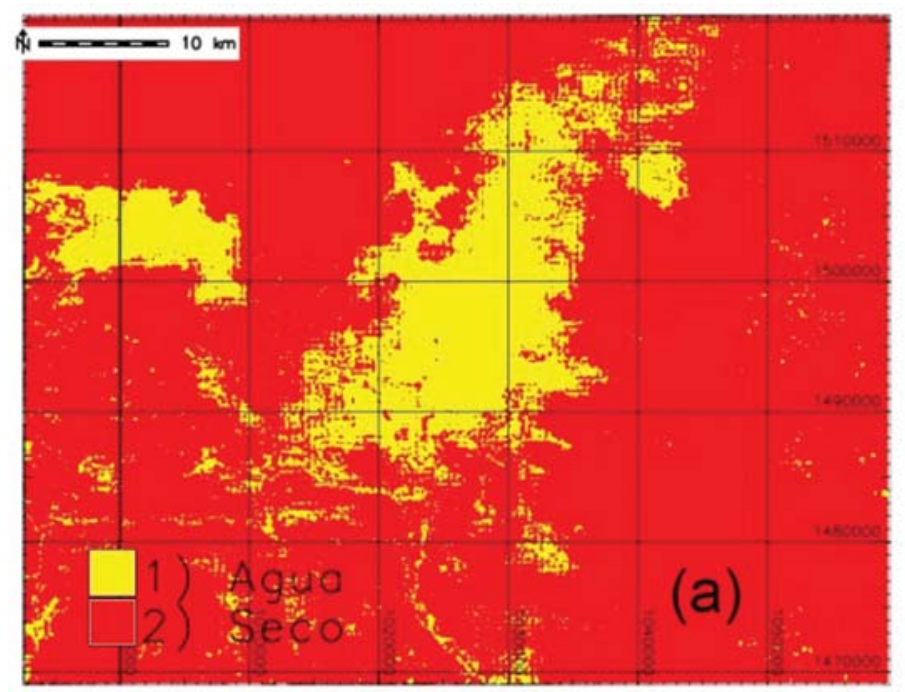

\subsection{Correction filters r. neighbors}

This part of the process can be alternated between the two previous parts that is the correction by filters can be executed before executing the module $i . d o d$, to reduce the noise; the effect of the $i . d o d$ module will be clearer. After the $i . d o d$ is also very effective to erase unnecessary data by the execution of this. This filter was executed with the popular criterion, and works with a neighborhood algorithm, that is, the most recurrent class in the neighborhood. At this point, the filters applied after the i.subpixel module and the i.dod module will be presented (Figure 7).

\subsection{Comparison methodologies}

To compare the methodologies in a more adequate way, the confusion matrices method between the supervised methodologies for the MODIS images versus the supervised classification executed for the Landsat images will be executed. Likewise, the sub-pixel methodology is compared with the supervised classification for Landsat images, in addition to this the error or deviation in the classifications with the reference methodologies is calculated with the Kappa index.

The evaluation criterion or variable was the number of sub-pixels or pixels of each map, identifying which class these belonged to, in order to obtain the number of pixels for each class and its corresponding area, the r.stats module was used, which facilitates this information.

The resulting maps are the main objective of this work, since the similarity and concordance of the sub-pixel classification of a MODIS image of 500 meters of spatial resolution is contrasted and appreciated, with the classification of an image with 30 meters and the notable

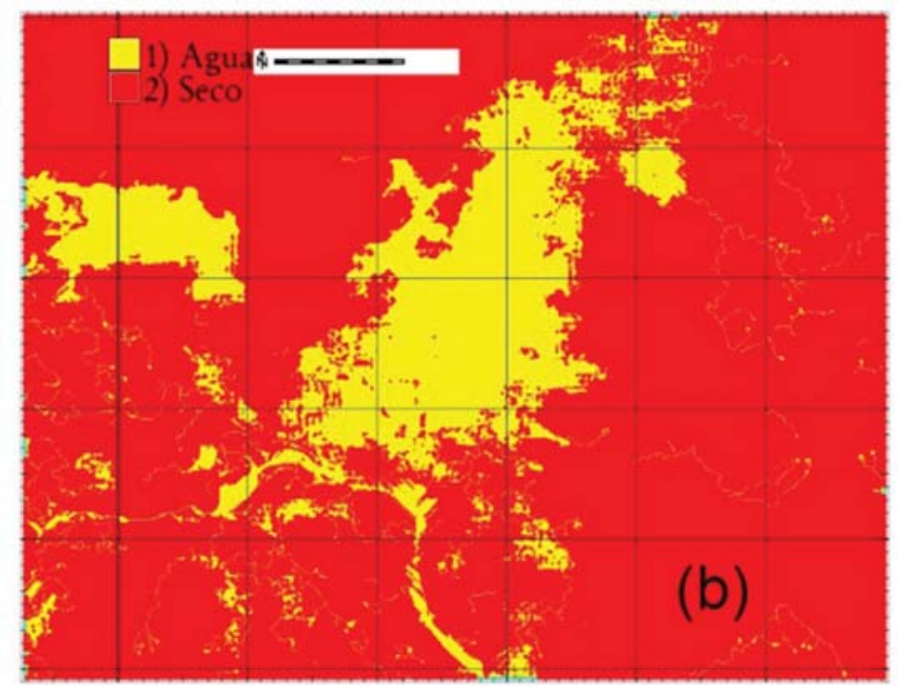

Figure 6. $a$ - classification module map i.subpixel; $b-i . d o d$ map classification 
difference of a common supervised classification of an image of moderate spatial resolution with a highresolution image.

Each map will be accompanied by the confusion matrix, which shows the quantification of the variation and the success of the supervised classification with MODIS and the sub-pixel classification with respect to the classification made to the Landsat image. In Figure 8, the comparison between the supervised classification for MODIS and Landsat will be shown.

On the map it is possible to appreciate the great water coverage that the MODIS image due to its limitations of spatial resolution fails to classify, especially the definition of the limits of the marsh and the Magdalena River, which is the body of water that generated this marsh, this variation is exposed in the following table.
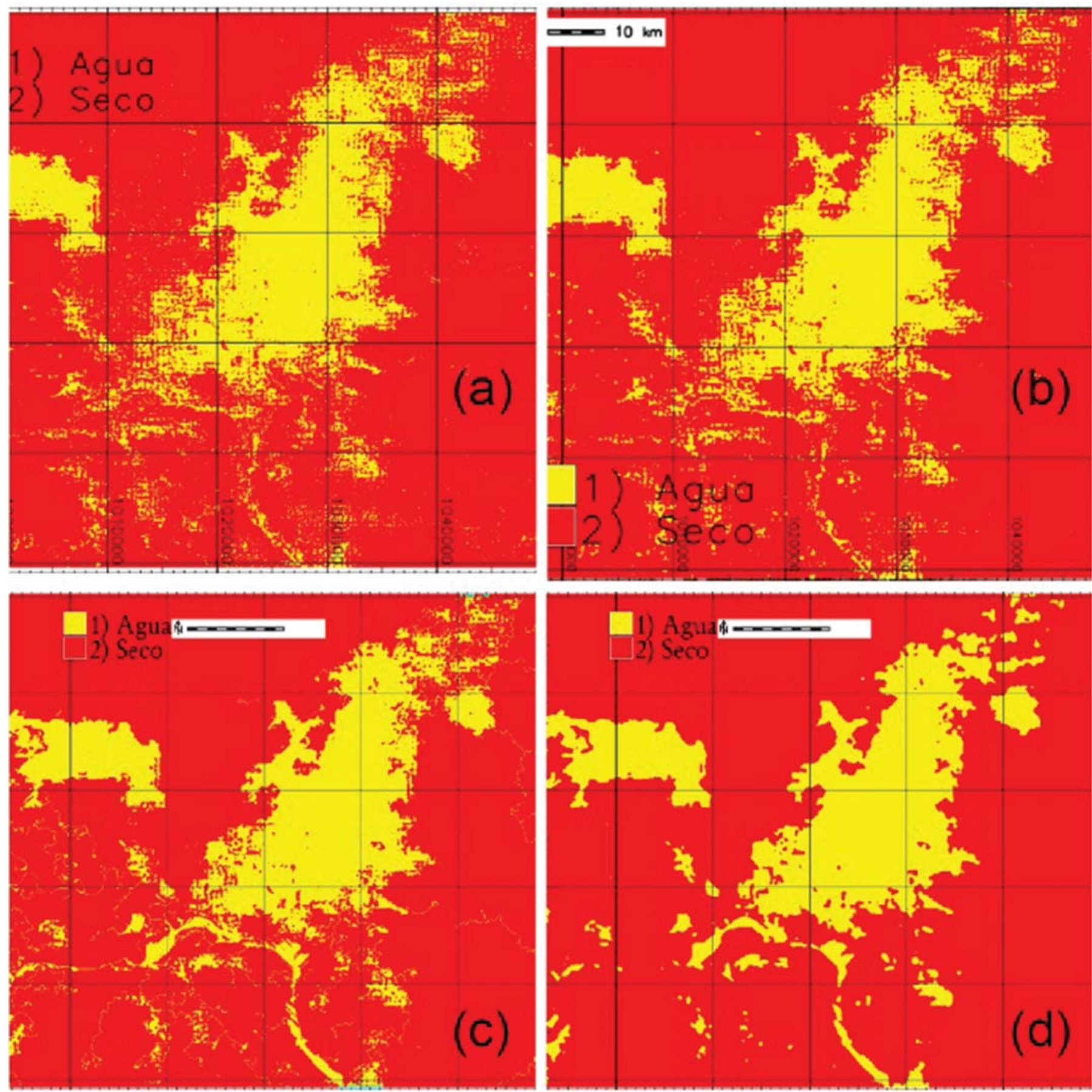

Figure 7. a - map i.subpixel; b-map i.subpixe/ with r.neighbors $3 \times 3 ; c-$ map i.dod; $d$ - map i.dod with $r . n e i g h b o r s ~ 9 \times 9$ 


\section{$50 \mathrm{~km}$}

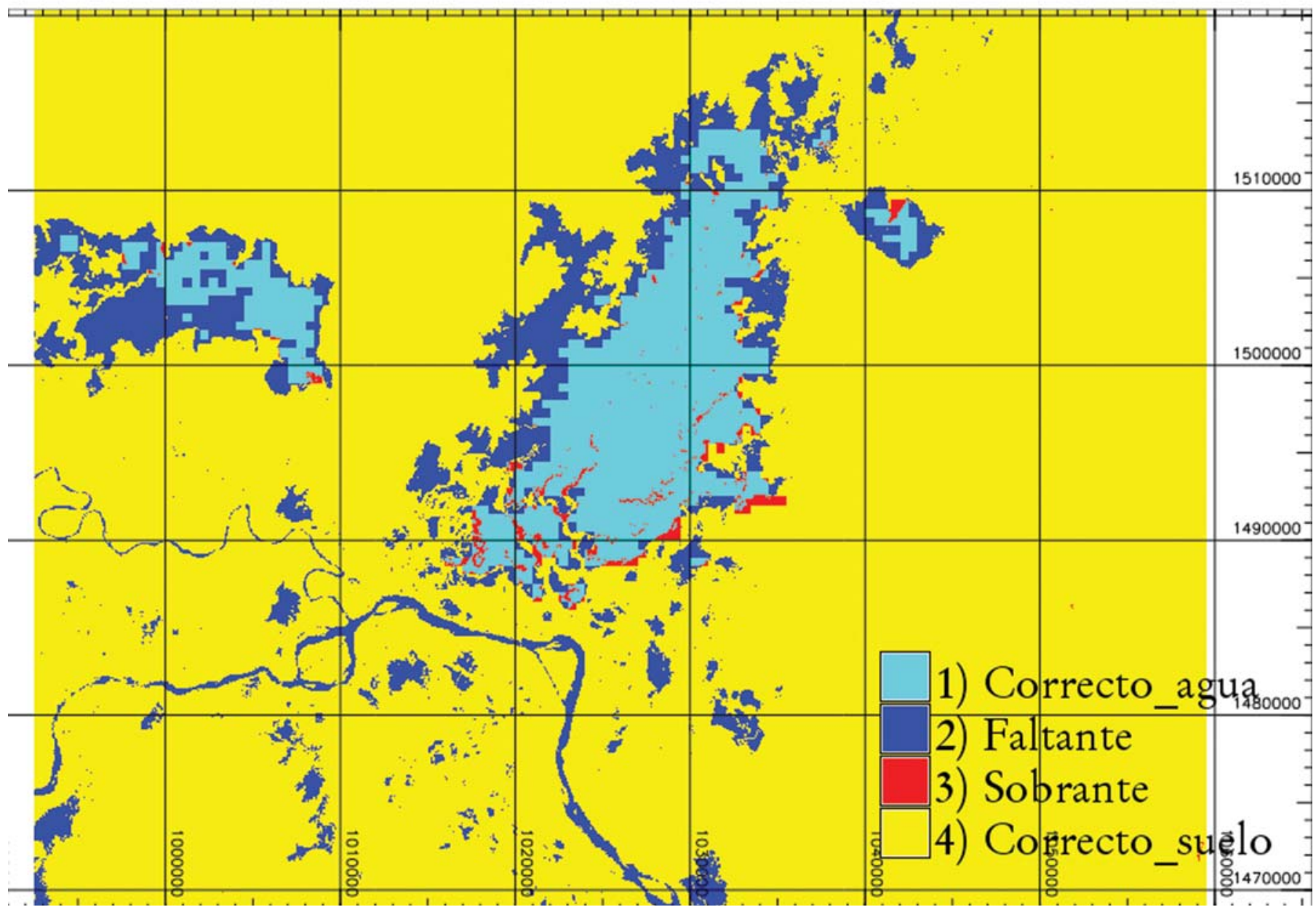

Figure 8. Validation of supervised classification for MODIS images based on supervised classification for Landsat:

1 - cyan: water properly mapped; 2 - blue: areas missing map; 3 - red: soil mapping as water; 4 - yellow: soil and vegetation correctly mapped

Table 1 this scale due to its poor accuracy evidenced in relation

Confusion matrix for supervised classification in MODIS versus supervised classification Landsat

\begin{tabular}{|c|c|c|c|c|}
\hline \multirow{2}{*}{} & \multicolumn{2}{|c|}{ Number of pixels } & \multicolumn{2}{c|}{ Percentage } \\
\cline { 2 - 5 } & Water & Dry & Water & Dry \\
\hline Water & 90922 & 6378 & $7 \%$ & $0.4685 \%$ \\
\hline Dry & 108496 & 1174331 & $8 \%$ & $86 \%$ \\
\hline
\end{tabular}

As it is possible to appreciate in the confusion matrix, the total 8 percent of the image stopped being classified as body of water by the MODIS images being this body percentage of water in the Landsat images, belonging to the river water bodies and the limits of the swamp, this deviation between the two classification is also quantifiable with the Kappa index that gave a value of $k=0.57$ (95\% confidence interval $= \pm 0.0023)$, which indicates in a statistical way that the data are moderately similar to each other.

It is noteworthy to say that the use of this classification is not suitable for the delimitation of bodies of water on to the capacity of a Landsat image.

Now we will compare the sub-pixel classification of the MODIS image against the supervised classification of a Landsat image. In Figure 9, there will be this comparison.

Table 2

Confusion matrix for sub-pixel classification in MODIS versus supervised classification in Landsat

\begin{tabular}{|c|c|c|c|c|}
\hline \multirow{2}{*}{} & \multicolumn{2}{|c|}{ Number of pixels } & \multicolumn{2}{c|}{ Percentage } \\
\cline { 2 - 5 } & Water & Dry & Water & Dry \\
\hline Water & 172332 & 26158 & $13 \%$ & two\% \\
\hline Dry & 60631 & 1102114 & $4 \%$ & $81 \%$ \\
\hline
\end{tabular}

Visibly on the map it is possible to appreciate that the sub-pixel classification covers mostly the body of water classified by the MODIS image, in addition to the body of water in its initial part, however it classifies dry zones as wet, being able to solve this with the validation of an image of better resolution, because the considerable 


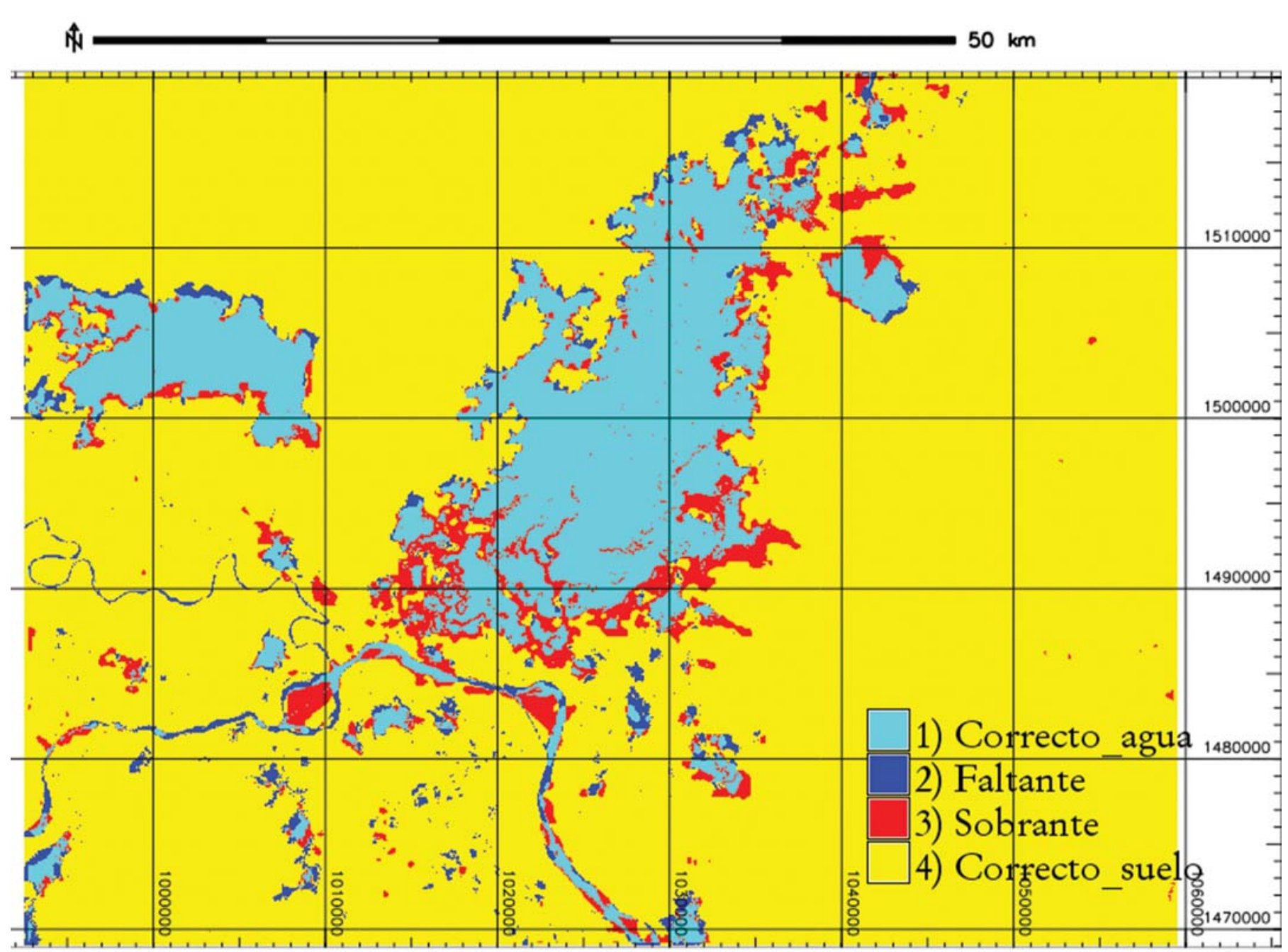

Figure 9. Validation of sub-pixel classification for MODIS images based on supervised classification for Landsat: 1 - cyan: water properly mapped; 2 - blue: areas missing from mapping; 3 - red: soil mapping as water; $4-$ yellow: soil and vegetation correctly mapped

error would be in the non-classification of bodies of water, to quantify this validation will be exposed the confusion matrix below.

Once having the results of the confusion matrix it is remarkable to see that $13 \%$ of the total water mapped is correct and is presented in the two methodologies, in addition to the great decrease in the error with a single missing of $4 \%$ and a single $2 \%$ of incorrectly mapped soil, however the inclusion of the DTM is not enough to capture the bodies of water in which the Magdalena River divides, this problem coming from the initial resolution of MODIS images which are unable to capture these details, due to the scale of the image, if we consider that the Kappa index is of a $k=0.76$ (95\% confidence interval $= \pm 0.0015)$ statistically checking the similarity between the two classifications, showing that the classification sub-pixel is effective and very attached to the results that can be obtained with the use of satellite images of high spatial resolution.

\section{Conclusions}

At the end of all the results it was verified that the classification of sub-pixels, which in this case involves the linear mix model (LMM), the spatial coherence analysis (SCA) of the i.subpixel module and the use of drainage networks and accumulation maps of the digital terrain module i.dod is truthful and similar to classifying information of high spatial resolution in a common way.

The inclusion of DTM information as the topographic attributes of this and derived information such as drainage networks and accumulation maps validate from other sides the classification made for the sub-pixels, considering their behavior, which is directly linked to the characteristics of the land, emulating its behavior thanks to the zones of accumulation and projecting the possible presence of water joining the previous characteristics and drainage networks. 
It was possible to perform the delimitation and classification of coverage of the "Cienaga de Zapatosa" using images of moderate spatial resolution through the use of the sub-pixel classification demonstrating improvements with respect to the common supervised classification method.

Since the use of images of moderate spatial resolution was the maximum of this work and was carried out successfully, it is possible to use positively the good temporal resolution that this type of information brings, making it possible to monitor the high dynamism of bodies of water.

The quality of the results of these classifications, whether these are the common ones or those proposed in this work, depend directly on the quality of the input data and on the concordance that these have with what it represents physically, for which it is necessary have a filter that evaluated the quality of these, before executing any type of classification.

The ability to obtain coverage information at the subpixel level of classified images makes this classification method a "soft" or more refined classification technique.

Since the access to the type of information used in this type of classifications, from the thickest to the most refined, is free, being this online route available to the entire population makes this technique an effective and highly economic tool for the development of research and inclusion in the projects and activities of developing countries.

Due to the great advantages it brings, both economically and operationally this technique has a very versatile and wide field of action with uses that can range from the construction of hazard or risk maps for bodies of water, monitoring of extensive bodies of water, delimitation of bodies of water, the use of different indices that allow focusing on different objectives, a number of uses that are based on the needs and that will contribute to research and data collection for scientific, economic and social uses.

\section{References}

[1] Rodriguez Chavez OE, Arredodndo Bautista HA. Manual para el manejo y procesamiento de imágenes satelitales obtenidas del sensor remoto MODIS de la NASA aplicado en estudios de ingenieria civil [tesis]. Bogotá; 2005. Available from: https://www.javeriana.edu.co/biblos/tesis/ ingenieria/tesis123.pdf

[2] Stanbury KB, Starr RM. Applications of Geographic Information Sistems (GIS) to habitat assessment and marine resource management. OCEANOLOGICA ACTA. 1999; 22(6): 699-703.
[3] Hinojosa OR. Monitoreo de la sequía en Chihuahua mediante un sistema de información geografica (GIS). El Cid Editor - Ingeniería. 2007.

[4] Fenta A, Kifle A. Spatial analysis of groundwater potential using remote sensing and GIS-based multi-criteria evaluation in Raya Valley, northern Ethiopia. Hydrogeology Journal. 2015;23: 195-206. doi:10.1080/01431161.2011.6 08091.

[5] Giraldo Osorio JD, García Galeano SG. Development of a sub-pixel analysis method applied to dynamic monitoring of floods. International Journal of Remote Sensing. 2012;33(7): 2277-2295.

[6] Garcia Galiano SG, Giraldo Osorio JD. Desarrollo de un modelo de análisis de subpíxeles para el seguimiento dinámico de inundaciones. Cartagena; 2008.

[7] $\mathrm{Hu} Y H$, Lee HB, Scarpace FL. Optimal Linear Spectral Unmixing. IEEE TRANSACTIONSON GEOSCIENCE AND REMOTE SENSING. 1999;37(1): 639-644. doi $10.1109 / 36.739139$

[8] Verhoeye J, De Wulf R. Sub-Pixel Mapping of Sahelian Wetlands using Multi-Temporal SPOT VEGETATION Images. Laboratory of Forest Management and Spatial Information Techniques Faculty of Agricultural and Applied Biological Sciences. Gent - Belgica; 2000.

[9] Hongen Z, Suhong L, Qizhong L, Jiancheng S. Sub-pixel lake mapping in Tibetan Planteau. Geoscience and Remote Sensing Symposium IEEE. 2004: 3073-3076. doi 10.1109/ IGARSS.2004.1370347

[10] Giacomelli A, Mancini M, Rosso R. Integration of ERS-1 Imgery and Digital Terrain Models for the Assessment of Flooded Areas. 3rd ERS SYMPOSIUM, Florence, 97; 2014 jul. 23; Milano, Italy. Aviable from: https://earth.esa.int/ workshops/ers97/papers/mancini/index-2.html

[11] Hualin X, Guanrong Y, Guiying LB. Spatial evaluation of the ecological importance basen on GIS for enviromental managment: a case study in Xingguo coutry of China. Ecological Indicators. 2014;51: 3-12. doi: 10.1016/j. ecolind.2014.08.042

[12] Klein Gebbinck MS. Descomposition of mixed pixel in remote sensing images to improve the area estimation of agricultural fields [dissertation]. Renkum; 1998. Available from: https:// repository.ubn.ru.nl/handle/2066/18654

[13] U.S. Geological Survey. Landsat 8 (L8) Data Users Handbook. 29 March 2016. Available from: http://landsat. usgs.gov/18handbook_section5.php

[14] United States of America: Landsat Science 2015-16. Available from: http://landsat.gsfc.nasa.gov/?p=3186

[15] Richards JA, Xiuping J. Remote Sensing Digital Image Analysis. 5th ed. Berlin: Springer; 2013.

[16] Zwenzner H, Voigt S. Improved estimation of flood parameters by combining space based SAR data with very high resolution digital elevation data. Earth System Sciences. 2009: $567-576$.

\section{For citation:}

Suárez Kozov N, Trujillo Osorio D, Giraldo Osorio J. Application of remote sensing for monitoring of flood areas. RUDN Journal of Engineering Researches. 2019;20(1): 66-78. DOI 10.22363/2312-8143-2019-20-1-66-78 (In Russ.) 
Научная статья

\title{
Применение дистанционного зондирования для мониторинга зон затопления
}

\author{
Н. Суарес Козов*, Д. Трухильо Осорио ${ }^{\dagger}$ Х. Хиральдо Осорио \\ * Российский университет дружбы народов, Российская Федерация, 117198, Москва, ул. Миклухо-Маклая, 6 \\ † Папский Ксаверианский университет, Колумбия, 11023, Богота, Carrera 7 No. 40-62
}

\section{История статьи:}

Поступила: 02 ноября 2018

Доработана: 15 января 2019

Принята: 29 января 2019

\section{Ключевые слова:}

дистанционное зондирование;

субпиксели;

затопленные районы;

разрешение;

покрытие
Традиционные методы измерения площадей затопления «на месте» иногда приводят к значительным ошибкам или затруднениям, особенно когда площади затопления увеличиваются. В настоящее время многие методики определения площадей затопления земель паводковыми водами с использованием аэрокосмической фотосъемки характеризуются относительной низкой стоимость при высокой достоверности данных. Динамическая природа паводкового затопления территорий обусловливает необходимость использования спутниковых изображений высокого разрешения с учетом временного фактора. Однако такие изображения, как правило, имеют низкое пространственное разрешение. В связи с этим традиционные методы классификации не являются достаточно надежными для очерчивания и мониторинга наводнений, так как используют «жесткие методы» классификации, присваивая уникальный тип покрытия большему пикселю. Кроме того, «сглаженные методы» имеют возможность назначать различные типы покрытий внутри толстого пикселя. Настоящее исследование посвящено применению методологии анализа субпикселей для мониторинга площадей во время наводнения. Улучшение делимитации достигается использованием топографических атрибутов, предоставляемых цифровой моделью местности. Эта методология была применена для мониторинга в Великой впадине Момпозина, в частности для того, чтобы очертить болото Сапатоза. Полученные результаты могут быть использованы для прогнозирования сезонных паводковых подтоплений территорий в Российской Федерации, а также в других странах, для которых характерны сезонные колебания уровня поверхностных вод.

\section{Список литературы}

[1] Rodriguez Chavez O.E., Arredodndo Bautista H.A. Manual para el manejo y procesamiento de imágenes satelitales obtenidas del sensor remoto MODIS de la NASA aplicado en estudios de ingenieria civil: Дис. Bogotá, 2005. URL: https://www.javeriana.edu.co/biblos/tesis/ingenieria/ tesis123.pdf (дата обращения: 12.06.2015).

[2] Stanbury K.B., Starr R.M. Applications of Geographic Information Sistems (GIS) to habitat assessment and marine resource management // OCEANOLOGICA ACTA. 1999. Vol. 22. No. 6. Pp. 699-703.

[3] Hinojosa O.R. Monitoreo de la sequía en Chihuahua mediante un sistema de información geografica (GIS) // El Cid Editor - Ingeniería. 2007.

[4] Fenta A., Kifle A. Spatial analysis of groundwater potential using remote sensing and GIS-based multi-criteria evaluation in Raya Valley, northern Ethiopia // Hydrogeology Journal. 2015. No. 23. Pp. 195-206.

[5] Giraldo Osorio J.D., García Galeano S.G. Development of a sub-pixel analysis method applied to dynamic monitoring of floods // International Journal of Remote Sensing. 2012. Vol. 33. No. 7. Pp. 2277-2295.

[6] Garcia Galiano S.G., Giraldo Osorio J.D. Desarrollo de un modelo de análisis de subpíxeles para el seguimiento dinámico de inundaciones. Cartagena, 2008.

[7] Hи Y.H., Lee H.B., Scarpace F.L. Optimal Linear Spectral Unmixing // IEEE Transactions on Geoscience and Remote Sensing. 1999. Vol. 37. No. 1. Pp. 639-644.

[8] Verhoeye J., De Wulf R. Sub-Pixel Mapping of Sahelian Wetlands using Multi-Temporal SPOT VEGETATION Images // Laboratory of Forest Management and Spatial Information Techniques Faculty of Agricultural and Applied Biological Sciences. Gent - Belgica, 2000.

[9] Hongen Z., Suhong L., Qizhong L., Jiancheng S. Sub-pixel lake mapping in Tibetan Planteau // Geoscience and Remote Sensing Symposium IEEE. 2004. Pp. 3073-3076.

[10] Giacomelli A., Mancini M., Rosso R. Integration of ERS-1 Imgery and Digital Terrain Models for the Assessment of Flooded Areas // 3rd ERS SYMPOSIUM, Florence, 97; 2014 jul. 23. Milano, Italy.

\footnotetext{
* Магистрант департамента строительства, Инженерная академия; nikolaysuarez@gmail.com

$\dagger$ Магистрант департамента строительства

¥ Доцент департамента строительства, Политехнический университет Картахены, кандидат технических наук по управлению водными ресурсами
} 
[11] Hualin X., Guanrong Y., Guiying L.B. Spatial evaluation of the ecological importance basen on GIS for enviromental managment: a case study in Xingguo coutry of China // Ecological Indicators. 2014. Vol. 51. Pp. 3-12.

[12] Klein Gebbinck M.S. Descomposition of mixed pixel in remote sensing images to improve the area estimation of agricultural fields: dissertation. Renkum, 1998.

[13] U.S. Geological Survey. Landsat 8 (L8) Data Users Handbook. URL: http://landsat.usgs.gov/18handbook_ section5.php (дата обращения: 09.03.2016).

[14] United States of America: Landsat Science 2015-16. URL: http://landsat.gsfc.nasa.gov/?p=3186 (дата обращения: 16.07.2016).

[15] Richards J.A., Xiuping J. Remote Sensing Digital Image Analysis. 5th ed. Berlin: Springer, 2013.
[16] Zwenzner $H$., Voigt $S$. Improved estimation of flood parameters by combining space based SAR data with very high resolution digital elevation data // Earth System Sciences. 2009. Pp. 567-576.

\section{Для цитирования:}

Suárez Kozov N., Trujillo Osorio D., Giraldo Osorio J. Application of remote sensing for monitoring of flood areas (Применение дистанционного зондирования для мониторинга зон затопления) // Вестник Российского университета дружбы народов. Серия: Инженерные исследования. 2019. Т. 20. № 1. C. 66-78. DOI 10.22363/23128143-2019-20-1-66-78 